\title{
SLAVoj ŽŻ̌̌EK
}

\section{„Guð er dauður en hann veit pað ekki“}

\section{Lacan leikur sér með Bobok ${ }^{1}$}

\begin{abstract}
Hin sanna kennisetning trúleysis er ekki Guð er dauður - jafnvel með pví að grundvalla upprunann á virkni föðurins í föðurmorðinu, verndar Freud föðurinn - hin sanna kennisetning trúleysis er Guð er dulvitaður.2
\end{abstract}

Til að skilja petta textabrot til hlítar parf að lesa aðra fullyrðingu Lacans samhliða pví.

Aðskildu staðhæfingarnar tvær ætti að fara með eins og hluta sömu ráðgátu sem parf að setja saman svo úr verði ein tillaga með samhengi. Einungis tengsl peirra (auk vísunarinnar í freudískan draum um föðurinn sem veit ekki að hann er dáinn) ${ }^{3}$ gera okkur kleift að útfæra grundvallarfullyrðingu Lacans í heild sinni.

1 [Kaflinn birtist upphaflega í bók Slavoj Žižek, How to Read Lacan, New York: WW Norton \& co., 2007, bls. 91-104. - Pýðandi.]

2 Jacques Lacan, The Four Fundamental Concepts of Psycho-Analysis, Harmondsworth: Penguin, 1979, bls. 59. [Síðasta málsgrein tilvitnunarinnar er orðrétt „God is unconscious“ og er leikur að margræðni enska orðsins unconscious. Ef orðið er lýsingarorð pýðir petta í raun að Guð sé meðvitundarlaus (og í dái) en ef ákveðnum greini væri skeytt framan við unconscious yrði Guð sjálf dulvitundin. Í íslensku pýðingunni er aðalatriðið undirstrikað, pað er að Guð er enn á sveimi í dulvitund hins trúlausa án pess að hann geri sér grein fyrir pví. - Pýðandi.]

3 Ef pessi draumur er lesinn í samhengi við túlkun á draumi í 3. kafla [bókar Žižeks, How to Read Lacan, "From Che vuoi? to Fantasy. Lacan with Eyes Wide Shut"] um dáinn son sem birtist föður sínum svo voveiflega og segir „Faðir, sérðu ekki að ég brenn?" má umorða staðhæfingu Lacans pannig að hún verði ásökun í garð GuðsFöður: „Faðir, sérðu ekki að pú ert dáinn?“ [Um drauminn sjá Jacques Lacan, The Four Fundamental Concepts of Psycho-Analysis, bls. 57-58. - Pýðandi.]

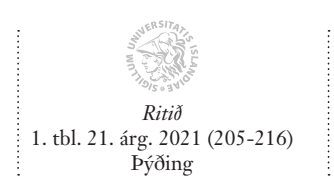
(C) 2021 Ritið, tímarit Hugvísindastofnunar og höfundur greinarinnar


Eins og alkunna er leiðir Ívan, sonur Karamazov föðurins, hinn síðarnefnda inn á pær hættulegu brautir sem hugsun hins fágaða manns fetar. Sérstaklega segir hann ef Guð er ekki til ... - ef Guð er ekki til, segir faðirinn, pá er allt leyfilegt. Hugmyndin er augljóslega barnaleg pví við sálgreinendur vitum ósköp vel að ef Guð er ekki til pá er alls ekkert leyfilegt lengur. Taugaveiklaðir sjúklingar færa okkur sönnur á pví hvern einasta dag. ${ }^{4}$

Trúleysingi nú á dögum telur sig vita að Guð sé dauður; hann veit hins vegar ekki að ómeðvitað heldur hann áfram að trúa á Guð. Dæmigerð ímynd hins trúaða manns, sem á laun efast um trú sína og gefur sig að syndsamlegum hugarórum, er ekki lengur einkennandi fyrir nútímann. Núna er hinn dæmigerði einstaklingur (e. subject) aftur á móti sá sem kynnir sjálfan sig sem umburðarlyndan nautnasegg og helgar líf sitt hamingjuleit. Dulvitund hans er vettvangur banna par eð óleyfilegar nautnir eða prár eru ekki lengur hið bælda heldur bönnin sjálf. „Ef Guð er ekki til er allt leyfilegt“ pýðir að pví sterkar sem maður skynjar sjálfan sig sem guðleysingja, peim mun betra tak hafa bönnin á dulvitundinni - og bönnin spilla ánægjunni. (Ekki má láta undir höfuð leggjast að bæta andstæðunni við. Ef Guð er til er allt leyfilegt - er petta ekki einhver gagnorðasta skilgreiningin á vandræðum bókstafstrúarmanna? Í huga bókstafstrúarmanns er tilvera Guðs alger og hann upplifir sjálfan sig sem verkfæri Hans. Pess vegna má hann gera allt sem hann vill, gjörðir hans eru fyrirfram réttlættar par sem pær tjá guðlegan vilja...)

Í stað pess að leiða til frelsis hleypti fall kúgandi yfirvalds af stokkunum nýjum og harkalegri bönnum. Hvernig er hægt að útskýra pessa pversögn? Gerið ykkur í hugarlund kringumstæður sem flest okkar kannast við úr bernsku; óheppna barnið sem um síðdegisbil á sunnudegi á að heimsækja ömmu sína en má ekki leika við vinina. Skilaboð gamaldags og skipandi föður til sonar síns hefðu verið: „Mér stendur á sama um hvernig pér líður. Sinntu bara skyldu pinni, farðu til ömmu pinnar og hagaðu pér eins og maður!“ Í pessu tilfelli eru vandræði barnsins ekki svo gífurleg pví pótt pað sé pvingað til að gera eitthvað sem er pví augljóslega pvert um geð varðveitir barnið innra frelsi og getur síðar meir gert uppreisn gegn valdi föðurins. Skilaboð póstmódernísks föður sem ekki er skipandi á ofangreindan hátt hefðu verið mun viðsjálli: „Pú veist hvað ömmu pinni pykir vænt um pig! Samt vil ég ekki pvinga pig til að heimsækja hana - pú ferð einungis ef pig raunverulega

4 Jacques Lacan, The Ego in Freud's Theory and in the Technique of Psychoanalysis, New York: Norton, 1988, bls. 128. 
langar!“ Sérhvert barn sem er ekki heimskt (og sjaldnast eru börn heimsk) ber undir eins kennsl á gildruna sem felst í pessu eftirlátssama viðhorfi. Að baki pví sem virðist vera frjálst val leynist krafa og í henni er að finna jafnvel meiri kúgun en í kröfu hefðbundna föðurins. Ekki er nóg með að í kröfunni sé undirliggjandi skipun um að heimsækja ömmuna heldur ber barninu að framfylgja skipuninni sjálfviljugt og af fúsum og frjálsum vilja. Falskt frjálst val af pessu tagi er ruddaleg skipun frá yfirsjálfinu (e. obscene superego injunction), skipun sem sviptir barnið meira að segja innra frelsi með pví að skipa pví hvað pað eigi að vilja gera - ekki bara hvað pað eigi að gera.

Áratugum saman hefur sígildur brandari gengið á milli Lacanista, en hann útskýrir hvernig pekking Hins skiptir sköpum. Maður nokkur heldur að hann sé frækorn og er færður á geðsjúkrahús. Læknar par reyna eftir fremsta megni að sannfæra hann um að hann sé ekki korn heldur maður og tekst pað að lokum. Pegar hann hefur „læknast“ (er sannfærður um að hann sé maður en ekki frækorn) er honum leyft að fara af sjúkrahúsinu en pá bregður svo við að hann kemur undir eins aftur skjálfandi á beinunum. Fyrir utan dyrnar er hæna og hann óttast að hún muni éta hann. „Kæri vinur,“ segir læknirinn, „pú veist ósköp vel að pú ert ekki frækorn heldur maður.“ „Auðvitað veit ég pað,“ svarar sjúklingurinn, „en veit hænan pað? “ Í pessu er að finna pað sem sannarlega er í húfi í sálgreiningu og sálgreiningarmeðferð. Ekki dugir að sannfæra sjúkling um dulvituð sannindi, sjálf dulvitundin verður að meðtaka sannindin.

Hið sama gildir um marxísku kenninguna um blætiseðli vörunnar:

Vara virðist við fyrstu sýn sjálfsagður og hversdagslegur hlutur. Greining hennar sýnir, að hún er mjög undarlegur hlutur, full af háspekilegri hártogun og guðfræðilegum heilabrotum. ${ }^{5}$

Marx heldur pví ekki fram að gagnrýni eigi að sýna fram á hvernig vara, sem virðist dularfull guðspekileg eining, hafi í raun orðið til úr „hversdagslegum“ ferlum í lífi fólks eins og venja er í orðræðu upplýsingarinnar. Pvert á móti staðhæfir hann að verkefni gagnrýninnar sé að grafa upp „háspekilega hártogun og guðfræðileg heilabrot“ í pví sem við fyrstu sýn virðist aðeins hversdagslegt viðfang. Blætiseðli vörunnar (sú trú okkar að vörur séu töfragripir gæddir frumspekilegum mætti) býr ekki í huga okkar og hvernig við (rang)skynjum raunveruleikann heldur í samfélagslegum raunveruleika okkar sem slíkum. Мeð öðrum orðum, pegar marxisti hittir borgaralegan

5 Karl Marx og Friedrich Engels, „Blætiseðli vörunnar og leyndardómur pess“, Úrvalsrit, I. bindi, Reykjavík: Heimskringla, 1968, bls. 210. 
pegn (e. subject) gegnsósa af blætisdýrkun vörunnar hljómar ásökun marxistans í garð pegnsins ekki svona: „Vel má vera að vörur virðist í pínum augum vera töfragripir gæddir sérlegum mætti, en í raun eru peir hlutgerð tjáning á tengslum á milli fólks.“ Ásökunin er frekar á pessa leið: „Pú gætir haldið að vörur birtist pér sem einföld, efnisleg mynd félagsvensla (til dæmis að peningar séu nokkurs konar inneignarnóta sem veiti pér rétt á hluta af afurðum samfélagsins) en svona virðist pér betta ekki vera í raun og veru. Með pví að taka pátt í samfélagslegum viðskiptum í pínum félagslega raunveruleika, ert pú talandi dæmi um pá óhugnanlegu staðreynd að vörur koma pér í raun fyrir sjónir sem töfragripir sem gæddir eru sérstökum mætti.“ Við getum ímyndað okkur að borgaralegur begn sæki námskeið í marxisma par sem blætiseðli vörunnar er til umfjöllunar. Að námskeiði loknu kemur hann að máli við kennara sinn og kvartar undan pví að enn sé hann fórnarlamb blætisdýrkunarinnar. Kennarinn segir við hann: „En núna veistu hvernig málum er háttað, pú veist að vörur eru ekkert annað en tjáningarform fyrir samfélagsleg tengsl og alls enga töfra er í peim að finna!“ Og nemandinn svarar: „Auðvitað veit ég petta allt saman, en vörurnar sem ég fæst við virðast ekki vita petta!“ Að pessu beindi einmitt Lacan staðhæfingu sinni um að hina sönnu kennisetningu guðleysis sé ekki að finna í orðunum „Guð er ekki til,“ heldur „Guð er dulvitaður.“ Til viðbótar pessu nægir að rifja upp pað sem Milena Jesenska skrifaði um Kafka í bréfi til Max Brod:

\section{Í hans huga eru fyrirbæri á borð við peninga, kauphöll, gjaldeyris- viðskipti, ritvél fyrst og fremst sveipuð fullkominni dulúð (og pað eru pau virkilega, bara ekki í okkar huga heldur annarra). ${ }^{6}$}

Hér tæpir Jesenska á Kafka á marxískum hátindi hans; borgaralegur pegn veit vissulega að peningar eru ekki gæddir töfrum, hann veit að peningar eru einungis viðfang sem táknar ákveðin félagstengsl en í raunveruleikanum hegðar hann sér engu að síður eins og honum beri að trúa pví að peningar séu töfrum gæddir. Petta veitir okkur nákvæma innsýn í heim Kafka. Kafka gat upplifað milliliðalaust pær draumórakenndu trúarskoðanir sem við „venjulega“ fólkið afneitum. „Töfrar“ Kafka eru hinir sömu og Marx sagði „guðspekilegan vanskapnað“ "vörunnar. Endur fyrir löngu póttumst við vera trúuð opinberlega en vorum efahyggjufólk innst inni og gerðum jafnvel gróft grín að opinberri trú okkar. Ef sú var reyndin standa mál á annan veg núna. Við höfum tilhneigingu til að lýsa yfir efahyggju/nautnahyggju/

6 Tilvitnun í Jana Cerna, Kafka's Milena, Evanston: Northwestern University Press, 1993, bls. 174 . 
afslöppuðu lífsviðhorfi en á laun sækja bæði trú og harðneskjuleg bönn að okkur hið innra. Með pennan bakgrunn til viðmiðunar má sjá hvar mistök Dostojevskís er að finna. Dostojevskí kom fram með róttækasta tilbrigðið við hugmyndina „Ef Guð er ekki til er allt leyfilegt“ 1 „Bobok“. „Bobok“ er furðulegasta smásaga höfundarins og enn ruglar hún túlkendur í ríminu. Er pessi undarlega „viðbjóðsfantasía“ einfaldlega afurð sem rekja má til geðveiki höfundar? Eða er sagan kaldranaleg vanhelgun, andstyggileg tilraun til að skopstæla sannleik hinnar guðdómlegu Opinberunarbókar eins og hann birtist í sjálfri Biblíunni?? Í „Bobok“ bjáist drykkjusjúkur, bókhneigður maður að nafni Ívan Ívanovijts af ofheyrnum:

Ég er farinn að sjá og heyra skrýtna hluti, ekki beint raddir heldur eins og einhver við hlið mér muldri „bobok, bobok, bobok!“

Hvað pýðir petta bobok? Ég verð að dreifa huganum. Ég fór út í leit að einhverju til að létta mér lundina, ég rakst á jarðarför.

Hann fylgir pví fjarskyldum ættingja til grafar. Síðan verður hann eftir í kirkjugarðinum og heyrir óvart kaldhæðnislegt og léttúðugt samtal hinna látnu án peirra vitundar.

Og ég veit ekki hvernig petta vildi til, en allt í einu fór ég að heyra ýmislegt. Í fyrstu veitti ég pví enga athygli og virti að vettugi. En samtalið hélt áfram. Ég heyrði kæfð hljóð líkt og púðar væru fyrir vitum peirra sem töluðu en samt voru hljóðin skýr og mjög nálæg. Ég rankaði við mér, settist upp og fór að hlusta gaumgæfilega.

Af pessum orðaskiptum ræður hann að mannleg meðvitund lifir um skeið eftir dauða efnislíkamans og heldur velli uns rotnun lýkur að fullu en hinir látnu tengja algjöra rotnun hræðilegu og surgandi hljóðlíkingarorði, orðinu „bobok“. Einn peirra segir:

Sem betur fer eigum við tvo til prjá mánuði eftir ólifaða en svo bobok! Ég legg til að við nýtum mánuðina tvo eins ánægjulega og hægt er og byrjum allt upp á nýtt á nýjum grunni. Herrar mínir! Ég legg til að við ýtum frá okkur allri skömm.

Í blábyrjun sögunnar er að finna undarlega neitun á orðum Rimbauds, Fe est un autre [Ég er annar]: „Petta er ekki ég; petta er algjörlega önnur manneskja.“ 
Hinir dauðu, sem gera sér grein fyrir pví að peir eru fullkomlega óbundnir veraldlegum skilyrðum, ákveða að skemmta hver öðrum með pví að segja sögur úr tilveru sinni í lifanda lífi.

„[...] en ég vil ekki að við ljúgum. Рað er algjört aðalatriði og eina sem skiptir einhverju máli. Maður getur ekki lifað á yfirborðinu án pess að ljúga pví líf og lygi eru sömu merkingar. En hér munum við skemmta okkur með pví að ljúga ekki. Látum allt flakka pví hvað sem hver segir hefur gröfin sitthvað til síns ágætis! Við skulum allir segja sögu okkar upphátt og ekki skammast okkar hætishót. Til að byrja með skal ég segja ykkur frá sjálfum mér. Ég bý yfir rándýrseðli skal ég segja ykkur. Pví var algjörlega haldið í heljargreipum rotinna fjötra parna uppi á yfirborðinu og svoleiðis rígbundið. Burtu með fjötrana og eyðum pessum tveimur mánuðum í blygðunarlausum sannindum! Berháttum okkur og verum allsberir!“

„Verum allsberir, verum allsberir!“ görguðu raddirnar allar sem ein." ${ }^{\prime \prime}$

Sá viðurstyggilegi ódaunn sem leggur fyrir vit Ívans Ívanovijts er ekki af rotnandi líkum heldur siðferðilegur ódaunn. Svo hnerrar Ívan Ívanovijts skyndilega og hinir látnu pagna; álögunum er aflétt og við erum á ný stödd í venjulegum raunveruleika:

Pegar hér var komið sögu hnerraði ég skyndilega. Рað gerðist upp úr purru og óvart en áhrifin voru sláandi. Allt varð hljótt og féll í dúnalogn eins og vænta má í kirkjugörðum, eins og draumur hvarf petta allt. Nú ríkti grafarpögn. Ég held ekki að peir hafi blygðast sín vegna nærveru minnar, peir höfðu ákveðið að ýta frá sér allri skömm! Í fimm mínútur beið ég - ekki eitt aukatekið orð, algjör kyrrð.

Míkhaíl Bakhtín sá fullkomna ímynd listsköpunar Dostojevskís í „Bobok“, allt höfundarverk hans í hnotskurn par sem meginstef pess birtist, nefnilega sú hugmynd að „allt sé leyfilegt“ ef hvorki Guð né ódauðleiki sálarinnar eru til. Í karnívalískum undirheimi lífs „á milli tveggja dauða“ eru allar reglur og hvers kyns ábyrgð látin lönd og leið. Hinir ódauðu geta ýtt frá sér allri

8 [Textinn er pýddur úr enskri býðingu smásögunnar eins og hann birtist í texta Žižeks. - Pýðandi.] 
blygðun, hegðað sér eins og vitfirringar og hlegið að heiðarleika og réttlæti. Siðfræðilegur hryllingur slíkrar sýnar felst í pví að hún afhjúpar takmörk hugmyndarinnar um „sannleik og sátt“. Tökum sem dæmi brotamann sem uppsker ekki nokkra siðferðilega hreinsun með játningum sínum en leiða pess pá heldur til aukinnar og ruddafenginnar nautnar.

„Ódauð“ staða hinna látnu er andstæð stöðu föðurins í draumi einum sem Freud skýrir frá. Par lifir faðirinn áfram í dulvitund dreymandans vegna pess að faðirinn veit ekki að hann er dáinn. Hinir látnu gera sér fullkomlega ljóst að peir eru dánir og meðvitundin um pað gerir peim einmitt kleift að firra sig allri skömm. En hvaða leyndarmáli halda hinir dauðu svo vandlega leyndu fyrir öllum dauðlegum mönnum? Við heyrum ekkert um blygðunarlaus sannindin í „Bobok“ - alltaf pegar draugar hinna látnu eru í pann mund að afhenda hlustandanum „góssið“ og segja frá sóðalegum leyndarmálum sínum, draga peir sig í hlé. Kannski svarar lausnin til peirrar sem er að finna í lok dæmisögunnar um dyrnar að lögunum í Réttarböldunum eftir Kafka? Pegar sveitamaður nokkur liggur á dánarbeði sínum kemst hann loks að pví, að dyrnar sem hann hafði árum saman beðið eftir að verða hleypt inn um, eru parna aðeins fyrir hann. Hvað ef „Bobok“ er einnig sviðsetning, líkin lofa að ljóstra upp sínum subbulegustu leyndarmálum til pess eins að lokka og heilla aumingja Ívan Ívanovijts? Með öðrum orðum, hvað ef sýning „hinna blygðunarlausu sanninda“ með lifandi líkum er ekkert annað en hugarsmíð hlustandans - og aukinheldur trúaðs hlustanda? Ekki má gleyma að á sögusviðinu sem Dostojevskí dregur upp er heimurinn ekki guðlaus. Talandi náir upplifa tilvist sína eftir (líffræðilegan) dauða og pað er í sjálfu sér sönnun á tilvist Guðs - Guð er hér og heldur peim á lifi eftir dauða, pess vegna geta peir sagt frá öllu.

Dostojevskí setur á svið trúarlega fantasíu og hún tengist ekki á nokkra lund ástandi sem mætti kenna við alvöru trúleysi, jafnvel pótt sviðsetningin eigi að sýna ógnvænlegan, guðlausan alheim par sem „allt er leyfilegt.“ Hvaða árátta knýr líkin til að taka pátt í ruddalegri hreinskilninni sem felst í að „segja frá öllu“? Lacanískt svar liggur í augum uppi: Yfirsjálfið - ekki sem siðferðisfulltrúi heldur sem ruddafengin fyrirmæli um að njóta. Með svarinu skapast innsýn í hugsanlega svæsnasta leyndarmálið sem líkin halda leyndu fyrir sögumanni. Hvötin sem rekur hina látnu til að segja blygðunarlaust ekkert nema sannleikann er ekki „frjáls“. Kringumstæðurnar eru ekki á pá lund að „nú getum við loksins sagt allt sem við vildum en gátum ekki vegna boða og banna venjulegs lífs." Pess í stað heldur grimmileg skipun yfirsjálfs hvötinni gangandi; draugarnir verða að taka pátt í pessum rudda- 
fengnu athöfnum. Ekki eru öll kurl komin til grafar pví ef pað sem hinir látnu halda leyndu fyrir sögumanni er áráttukennd náttúra ruddafenginnar ánægju peirra og ef fantasían sem hér um ræðir er trúarleg, pá parf að draga eina ályktun til viðbótar. Hún er sú að hinir ódauðu eru undir áráttukenndum álögum sem illur Guð hefur bneppt pá í. Par er mestu lygi Dostojevskís að finna. Hann setur fram óhugnanlega fantasíu um guðlausan alheim en í raun er fantasían gnostísk og fjallar á áhrifaríkan hátt um illan, ruddalegan Guð. Almennari lærdóm má draga af dæminu, nefnilega pann að pegar trúaðir höfundar fordæma guðleysi draga peir oft upp mynd af „guðlausum alheimi“ sem er í raun frávarp á bældri skuggahlið trúarinnar sjálfrar.

Ég hef hér að ofan stuðst við hugtakið „gnostisismi“ í nákvæmri merkingu, pað er höfnun á pví lykilatriði í gyðing-kristilegum heimi að sannleikann sé að finna í hinu ytra. Yfirgnæfandi rök eru fyrir nánum tengslum gyðingdóms og sálgreiningar og í báðum tilfellum er skelfilegur (trámatískur) samfundur í brennidepli; að mæta hyldýpi Hins sem práir, að mæta ógnvekjandi ásýnd Hins sem í órafjarlægð væntir einhvers af okkur en lætur ekki uppi hvað petta eitthvað er. Мeð óræðu kalli sínu skapar Guð Gyðinga upplausn í daglegt líf peirra, barnið tekst á við ráðgátuna um ánægju Hins (hér foreldranna). Gyðing-kristileg hugmynd um sannleika er algjörlega andstæð heiðnum og gnostískum hugmyndum (gyðing-kristileg sannleikshugmynd byggir á ytri, skelfilegum samfundi við guðdómlegt kall Drottins til Gyðingapjóðarinnar, við kall Drottins til Abrahams, við óútskýranlega náð - en ekkert af pessu er í neinu samræmi við áskapaða eiginleika okkar, ekki einu sinni meðfætt siðferði okkar). Í bæði heiðni og gnostisisma (sem færir Gyðing-kristilegt viðhorf aftur til baka í heiðni) er leið sannleikans hins vegar innra ferðalag sem leiðir til andlegrar sjálfshreinsunar; snúið er aftur til hins sanna innra sjálfs og sjálfið er „enduruppgötvað“. Kierkegaard hafði á réttu að standa pegar hann benti á að megin andstæður í andlegum veruleika hins vestræna heims væru Sókrates og Kristur; innra ferðalag endurminningar gegn endurfæðingu í kjölfar áfalls vegna samfundar í hinu ytra. Á gyðing-kristilegum vettvangi er Guð sjálfur aðalhrellirinn sem með harkalegu áreiti sínu skapar glundroða í samhljómi lífdaga okkar.

Enn pann dag í dag eru ummerki gnostisisma auðsjáanleg í hugmyndafræði sýndarrýmis. Sýndarsjálfið sem rennur frá einni tilviljanakenndri og tímabundinni holdtekju til annarrar með pví að breyta sér í sýndareiningu er draumur um sjálf sem losnar úr viðjum líkama sem náttúran áskapaði pví. Sá draumur er aftur tækni- og vísindaleg uppfylling gnostíska draumsins um sjálfið sem losnar undan hrörnun og lífleysi efnisveruleikans. Engan 
skyldi undra að fræðimenn sem fást við sýndarrými vísi aðallega í heimspeki Leibniz. Leibniz skynjaði heiminn sem svo að hann væri settur saman úr „mónöðum“ eða örsmáum kjörnum. Hver ein og einasta mónaða lifði útaf fyrir sig í innilokuðu rými innra sjálfs og enga glugga væri að finna út í umhverfið. Vart verður hjá pví komist að taka eftir hversu óhugnanlega mikið mónöðufræði Leibniz líkjast samfélagi sýndarrýmis sem nú er komið fram á sjónarsviðið. Í hinu síðarnefnda fara hönd í hönd hnattrænt samræmi og sjálfsveruhughyggja (e. solipsism) eins skringilegt og bað nú er. Sem sagt, sökkvum við ekki statt og stöðugt dýpra í sýndarrýmið samhliða pví að við hringum okkur upp í leibníska mónöðu? Pótt mónaðan sé án glugga sem opnast út í umheiminn speglast í henni sjálfri alheimurinn eins og hann leggur sig. Við verðum sífellt meiri mónöður án glugga að raunveruleikanum. Alein eigum við í gagnvirkum samskiptum við tölvuskjái og mætum aðeins sýndarverund en engu að síður sökkvum við æ dýpra í hnattrænt net og eigum á einu og sama andartakinu samskipti við gjörvalla veröldina.

Rýmið sem Dostojevskí ímyndaði sér og hinir ódauðu gátu talað hömlulaust í án pess að taka tillit til siðferðishafta, er fyrirboði gnostíska draumsins um sýndarverund. Рað góða við sýndarkynlíf er, að par eð samskiptin eru við sýndarfélaga, fyrirfinnst par engin áreitni. Innan sýndarrýmis er enginn áreittur pví við eigum ekki beint í samskiptum við raunverulegt fólk og við höfum fullt frelsi til að gefa sóðalegustu ímyndunum okkar lausan tauminn. Fyrir skömmu var pessi hlið sýndarrýmis tekin út að ystu mörkum í tillögu sem kom fram á sjónarsviðið á ný á meðal ákveðinna hópa í Bandaríkjunum. Par er lagt til að „hugsa upp á nýtt" réttindi náriðla, pað er að segja peirra sem prá að fremja samræðisverknað á líkum. Af hverju ættu peir ekki að fá prá sinni fullnægt? Hugmyndin var sú, að á sama hátt og fólk leyfir að líffæri pess séu notuð í læknisfræðilegum tilgangi ef pað fellur skyndilega frá, ætti líka að leyfa pví að gefa náriðlum líkin af sér. Pessi tillaga er lifandi dæmi um hvernig skilningur Kierkegaards á pví að eini góði nágranninn sé dáinn nágranni hlýtur viðurkenningu í pólitískum rétttrúnaði gegn áreitni. Dáinn nágranni - lík - er fullkominn rekkjunautur fyrir „umburðarlyndan“ einstakling sem engan vill áreita. Eðli málsins samkvæmt er ekki hægt að áreita lík og enn fremur getur lík ekki notið. Par með hverfur einnig hin truflandi ógn af umfram-ánægju sem annars myndi steðja að sjálfsveru sem gerir sér dælt við líkið.

Pótt orðið ,áreitni“ virðist vísa til staðreyndar sem skilgreina megi á skýran og einfaldan hátt, er pað eitt peirra orða sem orkar sérlega tvímælis pegar betur er að gáð og skapar og viðheldur hugmyndafræðilegri leynd. 
Grundvallarmerking hugtaksins lýtur að hrottafengnum staðreyndum á borð við nauðganir, barsmíðar og annars konar félagslegt ofbeldi sem ber auðvitað að fordæma afdráttarlaust. En án pess að pví hafi verið veitt nokkur eftirtekt hefur grundvallarmerking hugtaksins „áreitni“ runnið hljóðlaust saman við ríkjandi notkun pess, pað er fordæmingu á hvers kyns of mikilli nálægð við aðra raunverulega manneskju, prár hennar eða hans, hræðslu og nautnir. Nú á dögum ráða tvö pemu lögum og lofum um frjálslynt og umburðarlynt viðhorf til annarra: Virðing fyrir framandleika annarra og víðsýni annars vegar en hins vegar ofboðslegur og áráttukenndur ótti við áreitni. Hinn er í lagi svo framarlega sem nærvera hans er ekki uppáprengjandi, svo framarlega sem hann er ekki raunverulega annar. Umburðarlyndi fellur saman við andstæðu sína. Mér ber skylda til að vera umburðarlyndur í garð annars merkir í reynd að ég eigi ekki að nálgast hann um of, ekki ráðast inn á hans svæði. Í hnotskurn; mér ber að virða óumburðarlyndi hans/hennar gagnvart of mikilli nánd minni. Æ skýrar kemur einmitt petta fram í dagsljósið sem eitt af helstu „mannréttindum“ í síðkapítalistísku samfélagi, pað er að eiga rétt á pví að vera ekki áreittur, að vera haldið í öruggri fjarlægð frá öðrum.

Dómstólar í flestum vestrænum ríkjum setja nú á dögum nálgunarbann pegar einhver ákærir aðra manneskju fyrir áreitni (fyrir að elta hann/hana á röndum eða viðhafa óæskilega kynferðislega tilburði). Hægt er að banna með lögum peim sem áreitir að koma viljandi í námunda við fórnarlambið og honum gert skylt að halda sig í að minnsta kosti hundrað metra fjarlægð. Eins nauðsynlegar og pessar ráðstafanir eru má engu að síður finna í peim einhvers konar vörn gegn hinni skelfilegu Raun í prá Hins; liggur ekki í augum uppi hversu hrikalega ofbeldisfullt pað er að sýna fyrir opnum tjöldum ástríðu sína í garð annarrar manneskju? Eðli málsins samkvæmt pá meiðir ástríða viðfang sitt og jafnvel pótt viðtakandinn taki glaður að sér hlutskiptið mun hann eða hún aldrei komast hjá augnabliki óttablandinnar lotningar og undrunar. Еða, til að koma með enn eitt tilbrigðið við spakmæli Hegels: „Illskan leynist í pví sama augnaráði og skynjar illskuna allt í kringum sig“; óumburðarlyndi gagnvart Hinum leynist í pví sama augnaráði og skynjar allt í kringum sig óumburðarlynda og uppáprengjandi Hina.

Sérstaklega ætti að vera á varðbergi pegar karlmenn tala um kynferðislega áreitni gegn konum - málefni sem tröllríður öllu svo jaðrar við práhyggju. Pegar rétt hefur verið krafsað í „femínistavænt“ yfirborð hins pólitíska rétttrúnaðar hittir maður fyrir gömlu karlrembu-goðsögnina um konur sem hjálparvana verur og að pær beri ekki einungis að vernda fyrir ágengum 
körlum heldur fyrst og síðast fyrir sjálfum sér. Hjá karlrembunni sem pykist vera femínisti er vandamálið ekki að pær geti ekki varið sig heldur fari pær að njóta bess að vera áreittar kynferðislega - að karllæg ágengni hrindi af stað sjálfseyðileggjandi ferli sem vindi upp á sig í óhóflegri kynferðislegri ánægju. Í stuttu máli ætti að gaumgæfa hvers konar hugmynd um sjálfsveruleika felst óbeint í pessari práhyggju sem beinist að mismunandi tegundum áreitis, nefnilega hin narsissíska sjálfsvera. Og henni stafar sífelld ógn af öllu pví sem aðrir gera (ávarpar mig, horfir á mig...) og pví er Helvíti annað fólk eins og Sartre komst að orði fyrir margt löngu - L'enfer, c'est les autres. Um konur sem viðföng er skapa truflun og óróa pá er pað svo að pví huldari sem kona er peim mun frekar beinum við (karl)sjónum okkar að henni og pví sem leynist undir blæjunni. Talibanar létu sér ekki nægja að neyða konur til að hylja sig frá toppi til táar á almannafæri. Peir bönnuðu peim einnig að vera í skóm með mjög hörðum hælum (úr málmi eða tré) og skipuðu peim að ganga svo hljóðlega að ekki smylli um of í skónum pví pað gæti raskað innri ró karlanna, einbeitingu peirra og trúarhollustu. Pannig lítur einmitt pversögnin um umfram-ánægju út í sinni tærustu mynd: Ef rétt aðeins örlar á minnstu ummerkjum af huldu viðfangi verður truflunin sem af pví hlýst peim mun áhrifaríkari pví huldara sem viðfangið er.

Petta á einnig við um bönn við reykingum sem verða æx útbreiddari. Fyrst komu yfirlýsingar um „,reyklausar“ skrifstofur, svo flug, svo veitingastaði, svo flugvelli, svo bari, svo einkaklúbba, svo var bannað að reykja innan ákveðinnar fjarlægðar frá aðalinngöngum háskóla. Hjá bandarísku póstpjónustunni voru loks sígarettur máđar út af frímerkjum sem báru andlitsmyndir af blúsgítarleikaranum Robert Johnson sem og af Jackson Pollock. Рað verður að teljast alveg einstakt afrek í uppeldislegri ritskoðun og minnir um margt á pann stalínska sið að lagfæra ljósmyndir af nomenklatúrunni (valdaklíku flokksins). Bönnunum er beint gegn óhóflegri og áhættusamri ánægju annars, ánægju sem tekur á sig mynd pegar einhver kveikir sér ábyrgðarlaust í sígarettu og nýtur pess útí ystu æsar að taka djúpt ofan í sig (alveg andstætt uppunum frá Clinton-árunum sem púa sígarettur án pess að draga reykinn niður í lungun, njóta ásta án pess að eiginlegt samræði eigi sér stað og borða fitusnautt fæði) - einmitt eins og Lacan sagði, pað má ekkert lengur síðan Guð dó.

Meðal fastra umræðuefna í menningarrýni nú er að á tímum eftirlátssemi og frjálsræðis skorti börn skýr mörk eða bönn. Skorturinn vekur með peim gremju svo að pau hendast öfganna á milli. Einungis skýr mörk sem eitthvert táknrænt yfirvald setur getur tryggt stöðugleika og fullnægju - full- 
nægju sem hlýst af pví að brjóta bönn, fara yfir mörk. Til að skýra hvernig neitun virkar í dulvitundinni vísaði Freud til viðbragða sjúklings við draumi hans sjálfs sem snerist um ópekkta konu: „Hver svo sem pessi kona er pá veit ég að hún er ekki móðir mín. “ Í huga Freuds voru orðin augljós neikvæð sönnun fyrir pví að konan var móðir hans. Ekki finnst betri leið til að lýsa hinum dæmigerða sjúklingi núna en að ímynda sér gagnstæð viðbrögð hans við sama draumi: „Hver svo sem pessi kona í draumnum er pá er ég viss um að hann tengist á einhvern hátt móður minni!““

Venju samkvæmt var gert ráð fyrir að í sálgreiningu gæti sjúklingur unnið bug á hindrunum sem stæðu í vegi hans eða hennar til að njóta eðlilegrar fullnægingar í kynlífi; ef henni yrði ekki náð skyldi haldið til sálgreinandans og hann hjálpaði til við að losa um hömlurnar. Núna dynja á okkur alls kyns tilbrigði við eina og sömu fyrirskipunina - „njóttu!“ Pessar skipanir snerta ýmist hreina og beina ánægju í kynlífsathöfnum, eða ánægju vegna árangurs í starfi eða andlegrar vakningar. Ánægja virkar í reynd eins og undarleg siðferðisskylda: Einstaklingar finna til sektar en ekki vegna pess að peir hafi brotið siðferðisbönn og notið forboðinnar munúðar, heldur eru peir pjakaðir af sektarkennd vegna pess að peir eru ekki færir um að njóta. Við pessar kringumstæður er sálgreining eina orðræðan par sem manni leyfist að njóta ekki. Engum er bannað að njóta en engum er heldur pröngvað til pess - og prýstingnum er aflétt. 